O. Fahmy et al. Urol Oncol. 2018. Vol. 36, No. 2. P. 4343. DOI: https://doi.org/10.1016/j.urolonc.2017.10.002

12. Knoedler J., Frank I. Organ-sparing surgery in urology: partial cystectomy. Curr. Opin. Urol. 2015. Vol. 25. P. 111-115.

DOI: https://doi.org/10.1097/MOU.0000000000000145
13. Updated 2018 EAU Guidelines on Muscleinvasive and Metastatic Bladder Cancer/J. Alfred Witjes et al. Eur. Urol.

DOI: https://doi.org/10.1016/j.eururo.2016.06.020

The article was received 2020.09.18

\title{
COMPARATIVE ASSESSMENT OF CHANGES IN THE INCIDENCE OF TYPE I DIABETES MELLITUS IN THE REGIONS WITH ITS HIGH AND LOW INCIDENCE
}

\author{
Azerbaijan Medical University \\ Department III of Internal Diseases \\ Enver Kasumzade Str., 14, Baku, AZ1012, Republic of Azerbaijan \\ Азербайджанський медичний університет \\ III відділення внутрішніх хвороб \\ (зав. - д. мед. н., проф. А.А. Гидаятов) \\ вул. Енвер Касумзаде, 14, Баку, АZ1012, Азербайджанська Республіка \\ e-mail:aliyeva5657@uohk.com.cn
}

Цитування: Медичні перспективи. 2021. Т. 26, № 2. С. 180-187

Cited: Medicni perspektivi. 2021;26(2):180-187

Key words: changes, healthcare problems, diabetic retinopathy, epidemiological characteristics, least squares method Ключові слова: динаміка, проблеми охорони здоров'я, діабетична ретинопатія, епідеміологічна характеристика, метод найменших квадратів

Ключевые слова: динамика, проблемы здравоохранения, диабетическая ретинопатия, эпидемиологическая характеристика, метод наименьших квадратов

Abstract. Comparative assessment of changes in the incidence of type I diabetes mellitus in the regions with its high and low incidence. Aliyeva I.J. The purpose of this study was to determine dynamics of the levels of type I diabetes mellitus (DM) incidence in the regions with its different incidence. Material from the Azerbaijan Republican and Regional Registers of Diabetes Mellitus were used in this study. All cases of newly diagnosed type 1 DM and documented according to the clinical protocol in 2012-2016 were selected. At the first stage of the study, the rates of diabetes were identified in all administrative-territorial entities. Two groups from administrative-territorial entities were formed for further observation: the first group included regions with high (>80\%000) incidence of type 1 DM, the second group included regions with low (<40\% 
incidence were studied and a mean chronological incidence over five years (2012-2016) was determined. Morbidity rate in cities and regions of Azerbaijan in 2012 changed within a range from 5.4 to $294.8 \% 000$. The lowest incidence was observed in three districts: 5.4\% in Agjabedi, 5.8\% $\% 000$ in Jalilabad, $6.1 \% 000$ in Masalli. Very high incidence was observed in Shamkir (294.8\% $(32.2 \% 000)$ were closer to data from the districts with low incidence. Incidence in Shirvan (81.9\% 0000$)$ and Yexlakh (171.7\%000) districts was high, but lower than in Shamkir and Khachmaz districts. Type 1 DM incidence has significant interregional differences. Interregional differences in type 1 DM incidence do not depend on the age of the population; age-adjusted incidence of type $1 \mathrm{DM}$ is within a range of 5.0-77.4\% $\%$

Реферат. Порівняльна оцінка динаміки рівня захворюваності на цукровий діабет I типу в регіонах із високим та низьким її рівнем. Алісва І.Дж. Метою дослідження є виявлення особливостей динаміки рівня захворюваності на ЦД1 у регіонах з різним ї̈ рівнем. У роботі були використані матеріали Азербайджанського республіканського і регіонального реєстру цукрового діабету. Були відібрані всі випадки ЦД1, вперше виявлені за 2012-2016 роки та документовані відповідно до клінічного протоколу. На першому етапі дослідження було встановлено рівень захворюваності на ЦД1 у всіх адміністративно-територіальних утвореннях. 3 адміністративно-територіальних утворень були виділені для подальшого спостереження 2 групи: одна група включала регіони з високим (>80\% \%о00) рівнем захворюваності на ЦД1, а інша -регіони з низьким (<40\%0000) рівнем захворюваності на ЦД1. У наступних етапах спостерігалася динаміка захворюваності ЦД1 і визначався середній хронологічний рівень захворюваності за п'ять років (2012-2016 роки). У 2012 рочі в районах та містах республіканського підпорядкування рівень захворюваності населення на ЦД1 коливався в інтервалі від 5,4 до 294,8\%000 . Наймениа величина показника була в трьох районах: 5,4\%000 в Агджабеді, 5,8\% \%о0о у Джалілабад, 6,1\% у у Масалли. Дуже високий рівень захворюваності відзначався в районах Шемкір (294,8\%0000) $i$ Хачмаз (278,7\% \%о0о ). Ближче до районів з низьким рівнем показника були дані в Баку (30,6\% \%о0о) $i$ Нахічеванській АР (32,2\%000 ). Дані міста Ширван (81,9\%000) і Евлахського району (171,7\%000) були значно вищими, але істотно були менше, ніж у Шамкірі і Хачмазі. Захворюваність населення на ЦД1 має чітко виражену міжрегіональну відмінність. Міжрегіональна відмінність за рівнем захворюваності ЦД1 не пов'язана з віковим складом населення, стандартизований за віком рівень захворюваності на ЦД1 коливається в інтервалі 5,0-77,4\% \%000 .

Diabetes mellitus (DM) is a condition defined as an increase in blood glucose levels, a diagnostic test of which is glycated hemoglobin $\mathrm{HbA}_{1} \mathrm{C}$ [3]. Four main etiological categories are currently defined for diabetes mellitus; T1DM, T2DM, gestational diabetes mellitus and other specific types. T1DM is characterized by insulin deficiency due to destruction of pancreatic beta cells, resulting in absolute insulin deficiency [3]. T2DM is characterized by a combination of insulin resistance and beta cell deficiency associated with obesity and a sedentary lifestyle. Gestational diabetes develops during pregnancy. Other specific types of diabetes include: single gene mutations resulting in rare forms of diabetes; secondary diabetes following a number of diseases (pancreatitis, trauma or surgery on the pancreas); drug- or chemically-induced diabetes. Prediabetes is a condition of impaired glucose metabolism, fasting hyperglycemia and impaired glucose tolerance. This condition is detected only based on the oral glucose tolerance test (glucose 2 hours after exercise $\geq 7.8 \mathrm{mmol} / \mathrm{L}$ and $<11.1 \mathrm{mmol} / \mathrm{L}$ ). The WHO has established threshold values for the diagnosis of diabetes based on glucose in venous plasma, venous and capillary blood, respectively (mmol/L and $\mathrm{mg} / \mathrm{dL}$ ):
- increase in fasting glucose: $6.1(110) ; 5.0(90)$ and 5.6 (101);

- impaired glucose tolerance: $7.8(140)$; 6.5 (117) and 7.2 (130);

- diabetes: fasting $7.0(126) ; 5.8(104)$ and 6.5 (117);

- diabetes: 11.1 (200); 9.4 (169) and 10.3 (185)2 hours after taking $75 \mathrm{~g}$ of glucose.

In the modern world, the most acute medical and social healthcare problems are associated with diabetes, the burden of which is constantly increasing. In many countries, an increasing burden of diabetes has become the basis for the formation of state programs to combat diabetes and the state system for monitoring trends in incidence changes and prevalence of this pathology, as well as the state of healthcare [10]. A huge amount of data accumulated worldwide shows an increase in the global burden of diabetes, although there are still significant differences between countries both in the incidence of diabetes in general, T1DM and T2DM in particular, and in the incidence of all forms of diabetes $[5,7,9,12,14,15]$. There are significant, interdistrict (provincial) and interregional differences in the incidence and prevalence of diabetes mellitus $[2,4,8,13]$. Significant differences in the 
incidence of diabetes mellitus are observed between rural and urban populations.

It was shown that an increase in the risk of diabetes is associated with socio-economic and demographic factors characteristic of modern civilizations (aging of the population due to a decrease in birth rates and an increase in life expectancy; educational level and employment in the fields with less physical activity; changes in diet, etc.). Certain aspects of the role of these factors are highlighted in the works of scientists from different countries $[5,6,7,11]$. From epidemiological point of view, there are relatively little comprehensive studies of incidence, prevalence, mortality and disability associated with diabetes [3,9]. A high prevalence of type 2 diabetes mellitus has necessitated more intensive studies of the epidemiological characteristics of this pathology [1].

Type I diabetes mellitus is not well covered in the literature. Data in a diabetes register are better summarized in Scotland [10]. Data on primary incidence, prevalence, age and sex characteristics of epidemiological and clinical characteristics, mortality, glycemic control and complications of diabetes are presented. In 2014, the incidence of diabetes was $5.2 \%$, and in 2015 it increased (5.3\%). In the regions of Scotland, the incidence ranged from 4.5 to $6.1 \%$. Age-adjusted incidence of diabetes mellitus confirms the significance of regional differences. The lowest values of the actual and adjusted incidence of diabetes were observed in different regions (Lothian and Western Isles). The highest actual (Ayrshire and Arran) and adjusted (Lanarkshire) incidence was also observed in different regions. This confirms the significance of a regional risk factor for the incidence of diabetes. Diabetes rates among people over 64, depending on the regions of Scotland, ranged from $12.3 \%$ (Western Isles) to $16.7 \%$ (Lanarkshire). In 2007-2015, the incidence of DM increased $(4.10 ; 4.28 ; 4.41 ; 4.57$; $4.74 ; 4.92 ; 5.05 ; 5.19$ and $5.31 \%)$.

The Scottish Diabetes Register contains comprehensive information on the primary incidence of type 1 diabetes mellitus, which was $32 ; 37 ; 22 ; 19$; $12 ; 10 ; 4$ and $2 \%$ for ages $<10,10-19,20-29,30$ 39, 40-49, 50-59, 60-69, 70 and older (in 2015), respectively. The primary incidence of T1DM tends to decrease $(20 ; 19 ; 18 ; 18 ; 19 ; 19 ; 16 ; 17 ; 17 \% 000)$. The primary incidence of T1DM in the regions of Scotland ranged from 9\% (Orkney) to $3 \%$ (Shetland). The primary incidence of T2DM also varied across the regions (241\%000 in Lothian, $366 \%$ in Ayrshire and Arran).

According to data [1], in the Perm Region in 2002-2011, the incidence of type I diabetes mellitus
(T1DM) ranged between 11.2 and 12\% 1000 ; mean life expectancy of T1DM patients is relatively shorter (by more than 10 years) and tends to decrease. Diabetic retinopathy develops in $30.6 \%$ of adults with type 1 diabetes and $10 \%$ of patients with type 2 diabetes. In Azerbaijan, according to data [1], in 2000-2012, there was a 2-fold increase in the incidence of (newly diagnosed) type 1 diabetes (from 29.1 to 55.3 per 100 thousand people) and its prevalence (from 163 to 299 per 100 thousand people). These data show the relevance of the studies of the epidemiological characteristics of T1DM.

The purpose of this study was to identify changes in the incidence of type 1 diabetes mellitus in the regions with its different incidence.

\section{MATERIALS AND METHODS OF RESEARCH}

Data from the Azerbaijan Republican and Regional Register of Diabetes Mellitus were used in this study. Azerbaijan has 6 cities of republican subordination and more than 70 districts, which differ significantly in a degree of urbanization: Baku is a metropolis, an ancient urbanized city with a population of over 2 million; Sumgait and Ganja are big cities with populations of 332.9 thousand and 328.4 thousand, respectively (as of 2015). Ganja has a long history of urbanization, while Sumgait is a young industrial city. Mingachevir and Shirvan are medium-sized cities with populations of 101.6 thousand and 82.9 thousand, respectively (2015). Naftalan is a small town with a population of 9.7 thousand. All administrative-territorial entities (cities and regions) have endocrinological units which keep records of all cases of diabetes mellitus.

The study was conducted from January to August 2020. All cases of type 1 diabetes, newly diagnosed and documented according the clinical protocol in 2012-2016, were selected. At the first stage of the study, the level of T1DM incidence was established in all administrative-territorial entities (cities and districts of republican subordination and the Nakhichevan Autonomous Republic). For each administrative-territorial entity (ATE) of the Republic of Azerbaijan (Nakhichevan Autonomous Republic, cities and districts of republican subordination), based on data on the number of patients with type 1 diabetes and population, the incidence was calculated per 100 thousand of mean annual population and its mean error for a calendar year. In addition, the mean annual number of newly diagnosed patients with type 1 diabetes and mean population per year were established, which allowed for determination of the mean five-year incidence of diabetes. 
Interregional differences in the incidence were assessed using a paired comparison of ATE values using the Student-Fisher t-test. The significance of changes in the incidence by calendar years was also assessed using a paired comparison of annual data. From administrative-territorial entities, 2 groups were selected for further observation: one group included regions with a high $(>80 \%$ \%ooo $)$ T1DM incidence (Shirvan city, Yevlakh, Khachmaz and Shemkir districts), and the second group included regions with a low $(<40 \%$ incidence of T1DM (Masalli, Jalilabad, Agdash and Agdzhabadi districts; Nakhichevan Autonomous Republic). At subsequent stages, changes in the incidence of type 1 diabetes were followed up and the mean chronological incidence over five years (2012-2016) was determined. The mean chronological incidence (MCI) was determined (Level 1):

$$
M C I=\frac{\sum I C Y}{n},
$$

where ICY is the incidence by calendar year and $n$ is the number of calendar years.

Taking into account the importance of this parameter, its characteristics were obtained for all parameters of descriptive statistics: mean error and standard deviation, variance, interval, minimum and maximum value and degree of reliability. Changes in the incidence of DM during 2000-2016 were estimated using the least squares method, the trend line was described using various equations (linear, exponential, logarithmic, polynomial of varying degrees, power, and others) for approximation, among which the most accurate equation was chosen. The criterion for equation accuracy was a discrimination coefficient $\left(\mathrm{R}^{2}\right)$. To study DM prevalence, official statistical data on all cases of pathology by calendar year (2000-2016) were also used. The obtained data were statistically processed using the STATISTICA ${ }^{\circledR}$ for Windows 13.0 package (StatSoft Inc., license No. JPZ804I382130ARCN10-J).

To study the quantitative and qualitative features of the epidemic process in order to establish integrative potential and realized risks the epidemiological method was used [9]. The main trend of changes was estimated using the least squares method; a regression equation with a high approximation was chosen. Taking into account agerelated changes in the incidence of T1DM [1], age distribution within the population and newly diagnosed patients with DM in the compared regions was studied [7]. Using direct standardization, the age-adjusted incidence of T1DM was calculated for the compared regions. A direct method focuses on calculations of general intensive parameters in the populations of the same composition, therefore partial parameters were calculated in the compared regions, which showed true correlations in the studied populations. The mean age of the population in both ATE groups was considered a standard.

\section{RESULTS AND DISCUSSION}

In 2012, the incidence of T1DM ranged from $5.4 \pm 2.05$ to $294.8 \pm 12.0 \%$ in the districts and cities of republican subordination. The lowest value of the parameter was observed in three districts: $5.4 \pm 2.05 \%$ in Agjabadi, $5.8 \pm 1.68 \%$ in Jalilabad, $6.1 \pm 1.7 \%$ in Masalli. A very high incidence was observed in Shemkir $(294.8 \pm 12.0 \%$ \%ooo $)$ and Khachmaz $(278.7 \pm 12.82 \% 000)$ districts. Data in Agdash (30.6 $\pm 5.41 \% 000)$ and Nakhichevan AR $(32.2 \pm 2.71 \% 000)$ were closer to low incidence. Data from the city of Shirvan $(81.9 \pm 10.0 \% 000)$ and Yevlakh district $(171.7 \pm 11.77 \% 000)$ were significantly high, but significantly lower than in Shamkir and Khachmaz (Table 1).

In 2013, compared to 2012, the incidence of T1DM $(p<0.05)$ increased significantly in Shirvan and Masalli, decreased in Yevlakh, Khachmaz, Shamkir, Agdash and Nakhichevan. The ranks of administrative units in terms of the incidence of T1DM changed in 2012 and 2013, but they maintained statistically significant correlations (Spearman's rank correlation coefficient was 0.79; the critical coefficient value was 0.78 with a significance level $\alpha=0.02$ ). In 2014, compared to 2013, the incidence of T1DM did not change significantly in Shirvan, Shamkir, Masallah, Agjabadi, Agdash and Nakhichevan, decreased in Yevlakh and Khachmaz, and increased in Jalilabad. The ranks of administrative units also changed, but they maintained significant correlations (rank correlation coefficient was $0.78 ; \mathrm{p}<0.05$ ). In 2015, compared to 2014, the incidence of T1DM did not change in Shirvan, Khachmaz, Shamkir, Masallah, Agjabedi, Agdash, and significantly decreased in Yevlakh, Nakhichevan and Jalilabad. The rank-order correlation between administrative units was significant (Spearman's correlation coefficient 0.7).

In 2013, compared to 2015, the incidence of T1DM significantly decreased in Shirvan, Khachmaz, Shamkir, Masallah, increased in Yevlakh, Jalilabad, Nakhichevan, and did not change in Agjabadi and Agdash. At the same time, the correlation between the ranks of administrative units was significant (Spearman's correlation coefficient $0.75 ; \mathrm{p}<0.05)$. Therefore, in administrative units, the incidence of T1DM changed chaotically in 2012- 
2016, while their ranks remained relatively stable, which is confirmed by the significance of the Spearman's correlation coefficient. Trend studies of changes in the incidence of T1DM showed that the main trend showed growth in Shirvan, Masallah, Agjabedi, and decrease in other regions, which is described by well-approximated regression equations (except Jalilabad) (Y - incidence, $\mathrm{x}-$ sequential numbers of years):

Shirvan $-Y=-15.045 x^{2}+91.449 x+4.1276$

$\left(\mathrm{R}^{2}=0.88\right)$;

Yevlakh $-\mathrm{Y}=14.83 \mathrm{x}^{2}-119.22 \mathrm{x}+277.69$

$\left(\mathrm{R}^{2}=0.98\right)$;
Khachmaz $-\mathrm{Y}=-66.397 \mathrm{x}+298.09\left(\mathrm{R}^{2}=0.81\right)$;

Shamkir $-\mathrm{Y}=10.397 \mathrm{x}^{2}-117.69 \mathrm{x}+373.1$

$\left(\mathrm{R}^{2}=0.81\right)$;

Masalli $-\mathrm{Y}=-0.6275 \mathrm{x} 3+3.62 \mathrm{x}^{2}-1.245 \mathrm{x}+5.1359$

$\left(\mathrm{R}^{2}=0.68\right)$;

Jalilabad $-\mathrm{Y}=-4.98 \mathrm{x}^{2}+29.75 \mathrm{x}-19.9\left(\mathrm{R}^{2}=0.27\right)$;

Agjabedi $-\mathrm{Y}=2.0331 \mathrm{x}^{2}-8.7648 \mathrm{x}+12.86$

$\left(\mathrm{R}^{2}=0.9576\right)$;

Agdash $-\mathrm{Y}=3.9683 \mathrm{x}^{2}-29.756 \mathrm{x}+54.035$

$\left(\mathrm{R}^{2}=0.90\right)$;

Nakhichevan AR $-\mathrm{Y}=3.746 \mathrm{x}^{2}-27.498 \mathrm{x}+53.525$ $\left(\mathrm{R}^{2}=0.88\right)$.

Table 1

\section{Changes in the incidence of T1DM in regions with high (Shirvan, Yevlakh, Khachmaz and Shamkir) and low (Masalli, Jalilabad, Agdash, Agjabadi, Nakhichevan) incidence}

\begin{tabular}{|c|c|c|c|c|c|c|c|}
\hline Years & $\begin{array}{l}\text { 2012, } \\
\mathbf{P} \pm \mathbf{m}\end{array}$ & $\begin{array}{l}\text { 2013, } \\
\mathbf{P} \pm \mathbf{m}\end{array}$ & $\begin{array}{l}\text { 2014, } \\
\mathbf{P} \pm \mathbf{m}\end{array}$ & $\begin{array}{l}2015 \\
\mathbf{P} \pm \mathbf{m}\end{array}$ & $\begin{array}{l}2016 \\
\mathbf{P} \pm \mathbf{m}\end{array}$ & 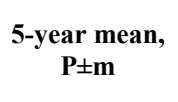 & $\begin{array}{c}\text { Age- } \\
\text { adjusted, } \\
\mathbf{P} \pm \mathbf{m}\end{array}$ \\
\hline $\begin{array}{l}\text { The city of } \\
\text { Shirvan }\end{array}$ & $\begin{array}{c}81.9 \pm 10.0 \\
(6)\end{array}$ & $\begin{array}{c}128.4 \pm 12.52 \\
(8)\end{array}$ & $\begin{array}{c}13.03 \pm 12.61 \\
(9)\end{array}$ & $\begin{array}{c}144.8 \pm 13.29 \\
(9)\end{array}$ & $\begin{array}{c}79.6 \pm 9.86 \\
(9)\end{array}$ & $\begin{array}{c}12.4 \pm 11.63 \\
(8)\end{array}$ & $\overline{77.4}$ \\
\hline $\begin{array}{l}\text { Yevlakh } \\
\text { district }\end{array}$ & $\begin{array}{c}171.7 \pm 11.77 \\
\text { (7) }\end{array}$ & $\begin{array}{c}98.8 \pm 8.93 \\
(6)\end{array}$ & $\begin{array}{c}62.6 \pm 7.11 \\
(7)\end{array}$ & $\begin{array}{l}25.7 \pm 4.55 \\
\quad(7)\end{array}$ & $\begin{array}{c}57.0 \pm 6.79 \\
(8)\end{array}$ & $\begin{array}{l}82.7 \pm 8.14 \\
\text { (6) }\end{array}$ & 58.9 \\
\hline $\begin{array}{l}\text { Khachmaz } \\
\text { district }\end{array}$ & $\begin{array}{l}278.7 \pm 12.82 \\
\text { (8) }\end{array}$ & $\begin{array}{l}156.8 \pm 9.62 \\
(9)\end{array}$ & $\begin{array}{c}21.6 \pm 3.57 \\
(5)\end{array}$ & $\begin{array}{l}24.5 \pm 3.81 \\
\quad(6)\end{array}$ & $\begin{array}{c}12.9 \pm 2.75 \\
(5)\end{array}$ & $\begin{array}{c}97.8 \pm 7.55 \\
(7)\end{array}$ & 13.5 \\
\hline $\begin{array}{l}\text { Shamkir } \\
\text { district }\end{array}$ & $\begin{array}{l}294.8 \pm 12.0 \\
(9)\end{array}$ & $\begin{array}{l}117.2 \pm 7.57 \\
\text { (7) }\end{array}$ & $\begin{array}{l}126.1 \pm 7.86 \\
(8)\end{array}$ & $\begin{array}{l}114.1 \pm 7.47 \\
(8)\end{array}$ & $\begin{array}{c}19.8 \pm 3.11 \\
(6)\end{array}$ & $\begin{array}{l}133.2 \pm 8.01 \\
\text { (9) }\end{array}$ & 20.2 \\
\hline Masalli district & $\begin{array}{c}6.1 \pm 1.70 \\
\text { (3) }\end{array}$ & $\begin{array}{l}15.1 \pm 2.66 \\
(5)\end{array}$ & $\begin{array}{c}12.6 \pm 2.43 \\
(4)\end{array}$ & $\begin{array}{l}20.9 \pm 3.14 \\
(5)\end{array}$ & $\begin{array}{c}10.2 \pm 2.19 \\
\text { (3) }\end{array}$ & $\begin{array}{c}12.9 \pm 2.44 \\
\text { (4) }\end{array}$ & 10.0 \\
\hline $\begin{array}{l}\text { Jalilabad } \\
\text { district }\end{array}$ & $\begin{array}{l}5.8 \pm 1.68 \\
\text { (2) }\end{array}$ & $\begin{array}{c}10.7 \pm 2.28 \\
\text { (4) }\end{array}$ & $\begin{array}{c}45.9 \pm 4.72 \\
(6)\end{array}$ & $\begin{array}{l}- \\
\text { (1) }\end{array}$ & $\begin{array}{c}10.5 \pm 2.26 \\
\text { (4) }\end{array}$ & $\begin{array}{l}14.5 \pm 2.63 \\
(5)\end{array}$ & 7.9 \\
\hline $\begin{array}{l}\text { Agjabadi } \\
\text { district }\end{array}$ & $\begin{array}{l}5.4 \pm 2.05 \\
\text { (1) }\end{array}$ & $\begin{array}{l}5.4 \pm 2.05 \\
\text { (1) }\end{array}$ & $\begin{array}{l}3.1 \pm 1.54 \\
\text { (2) }\end{array}$ & $\begin{array}{l}10.7 \pm 2.88 \\
\quad(4)\end{array}$ & $\begin{array}{c}20.0 \pm 3.94 \\
\text { (7) }\end{array}$ & $\begin{array}{l}8.9 \pm 2.61 \\
\text { (2) }\end{array}$ & 20.2 \\
\hline $\begin{array}{l}\text { Agdash } \\
\text { district }\end{array}$ & $\begin{array}{c}30.6 \pm 5.41 \\
\text { (4) }\end{array}$ & $\begin{array}{c}5.8 \pm 2.34 \\
\text { (2) }\end{array}$ & $\begin{array}{c}- \\
\text { (1) }\end{array}$ & $\begin{array}{l}3.8 \pm 1.91 \\
(2)\end{array}$ & $\begin{array}{c}5.4 \pm 1.34 \\
\text { (1) }\end{array}$ & $\begin{array}{l}8.3 \pm 2.81 \\
\text { (1) }\end{array}$ & 5.0 \\
\hline $\begin{array}{l}\text { Nakhichevan } \\
\text { AR }\end{array}$ & $\begin{array}{c}32.2 \pm 2.71 \\
(5)\end{array}$ & $\begin{array}{c}7.4 \pm 1.29 \\
\text { (3) }\end{array}$ & $\begin{array}{c}8.9 \pm 1.43 \\
\text { (3) }\end{array}$ & $\begin{array}{c}4.1 \pm 0.96 \\
(3)\end{array}$ & $\begin{array}{l}8.6 \pm 1.41 \\
\text { (2) }\end{array}$ & $\begin{array}{l}12.1 \pm 1.66 \\
(3)\end{array}$ & 8.9 \\
\hline
\end{tabular}

The interregional differences were significant for all years of observation, the ratio of the highest to the lowest incidence of T1DM was $54 ; 29 ; 42 ; 38$; 15 in 2012-2016. The mean incidence of T1DM over 5 years was: $112.4 \pm 11.63 \%$ in Shirvan, $82.7 \pm 8.1 \%$ in Yevlakh, $97.8 \pm 7.55 \%$ in Khachmaz, $133.2 \pm 8.01 \%$ in Shamkir, $12.9 \pm 2.44 \%$ in Masalli, $14.5 \pm 2.63 \%$ in Jalilabad, $8.9 \pm 2.61 \%$ in Agjabadi, $8.3 \pm 2.81 \% 000$ in Agdash, $12.1 \pm 1.66 \%$ in Nakhichevan AR. Obviously, according to 5-year data, the administrative-territorial entities differed significantly; Shirvan, Yevlakh, Khachmaz and Shamkir were regions with a high incidence $(>80 \% 000)$, and the rest of the regions had a low $(<40 \%$ incidence of T1DM. The reason for interdistrict differences may be different age distribution of the population (Table 2). 


\section{Age distribution in communities with high (Shirvan, Yevlakh, Khachmaz, Shamkir)} and low (Masalli, Jalilabad, Agjabedi, Agdash, Nakhichevan) incidence of T1DM (2016)

\begin{tabular}{|c|c|c|c|c|c|}
\hline Age/Community & $0-14$ & $15-29$ & $30-44$ & $45-59$ & $60+$ \\
\hline The city of Shirvan & 19.44 & 28.71 & 22.75 & 19.99 & 9.1 \\
\hline Yevlakh district & 25.43 & 26.53 & 20.46 & 18.63 & 8.95 \\
\hline Khachmaz district & 24.55 & 27.02 & 20.46 & 19.37 & 8.6 \\
\hline Shamkir district & 24.5 & 27.12 & 20.17 & 19.27 & 8.94 \\
\hline Masalli district & 25.36 & 26.93 & 22.13 & 17.69 & 7.89 \\
\hline Jalilabad district & 24.89 & 29.76 & 21.82 & 16.56 & 6.97 \\
\hline Agjabadi district & 25.8 & 27.32 & 21.09 & 18.28 & 7.51 \\
\hline Agdash district & 23.48 & 26.97 & 20.74 & 20.38 & 8.43 \\
\hline Nakhichevan AR & 24.98 & 27.02 & 21.35 & 18.28 & 8.37 \\
\hline Total (standard) & 24.31 & 27.49 & 21.20 & 18.69 & 8.31 \\
\hline
\end{tabular}

In 2016, the proportion of age groups of $15-44$ years (high probability of T1DM onset) was $51.46 \%$ in Shirvan, $46.99 \%$ in Yevlakh, $47.48 \%$ in Khachmaz, $47.29 \%$ in Shamkir, $49.06 \%$ in Masalli, $51.58 \%$ in Jalilabad, $48.41 \%$ in Agjabadi, $47.71 \%$ in Agdash and $48.37 \%$ in Nakhichevan. Age distribution of the patients with newly diagnosed T1DM in 2016 showed that the majority was 15-29 (41.9\%) and $30-44(44.8 \%)$ years old; the proportion of patients 0-14 years old and over 44 years old was significantly lower (4.5 and $1.9 \%)$. The incidence of T1DM in 2016, according to all studied regions, was $3.4 \% 000$ at the age of $0-14$ years, $28.0 \%$ at the age of $15-29$ years, $44.8 \%$ at the age of $30-44$, $2.0 \%$ at the age of 45-49 years old. The calculation of standardized T1DM levels in 2016 (distribution of the population in the studied regions was used as a standard - Table 2) showed that they did not differ from the actual data in the regions (Table 2). This confirms that the incidence of T1DM has significant interregional differences.

A five-year incidence of T1DM in the regions of Azerbaijan (82.7-133.2\% $\% 000$ ) classified as areas with a high incidence (Shirvan, Yevlakh, Khachmaz and Shamkir) is close to that in the Perm region of Russia (112-127\%000 ). Regions classified as areas with a low incidence of T1DM have a multifold lower incidence (8.3-14.5\% $\% 000$ ). In all districts, the incidence of T1DM is changing over time, although [1] notes a relative stability of the incidence in the
Perm Territory. Variability in changes in the incidence of T1DM in the regions of Azerbaijan and the significance of interregional differences indicate the objective justification of the observed parameters. Moreover, the role of the age factor in the formation of these parameters is not confirmed. The main trend in the changes in the incidence of T1DM also has interdistrict differences and the nature of changes does not depend on the incidence at the beginning of observation.

\section{CONCLUSIONS}

1. The incidence of T1DM has significant interregional differences.

2. The ratio of the highest to the lowest incidence of T1DM in 2012-2016 changes within a wide range (15-54) in the regions.

3. A five-year incidence of T1DM is high in Shamkir (133.2 $\pm 8.0 \% 0000)$, Shirvan $(112.4 \pm 11.63 \% 000)$, Khachmaz $(97.8 \pm 7.55 \% 000)$ and Yevlakh $(82.7 \pm 8.14 \% 000)$; multifold lower in Agdash $(8.3 \pm 2.81 \% 000)$, Agjabadi $(8.9 \pm 2.61 \% 000)$, Na-

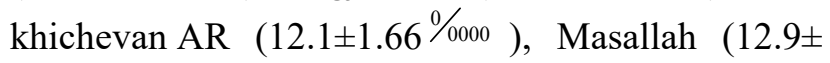
$\pm 2.44 \%$ ) and Jalilabad (14.5 $\pm 2.63 \% 000)$.

4. The interregional differences in the incidence of T1DM are not associated with age distribution among population; the age-adjusted incidence of T1DM varies within a range of 5.0-77.4\% $\%$ 
5. The main trend in the changes in the incidence of T1DM in Shirvan, Masallah and Agjabedi is an upward trend; in Yevlakh, Khachmaz, Shamkir, Jalilabad, Agdash and Nakhichevan is a downward trend.
Conflict of interests. The author declares no conflict of interest.

Acknowledgments. The author is grateful to the Organization of endocrinological care.

\section{REFERENCES}

1. Agaeva KF, Huseynli AF. [Features of the prevalence of diabetes mellitus and its age dynamics at the present stage of economic development among the population of the former Soviet industrial city]. Public Health and Health Care. 2014;3:22-24. Russian.

2. Vikulova OK. [State Register of Diabetes Mellitus of the Russian Federation: status 2015 and data from studies with active screening of the "Diabetes - center" module]. [Internet]; 2016. Available from: Diaregistry.ru. Russian.

3. Dedov II, Shestakova MV, Vikulova OK. [State Register of Diabetes Mellitus in the Russian Federation; 2014 status and development prospects]. Diabetes Mellitus. 2015;18(3):5-23. Russian.

doi: https://doi.org/10.14341/DM201535-22

4. Sultanalieva RB, Sagynova SK, Albakova AO, Knyazeva VG, Dobrynina NP. [Epidemiological aspects of diabetes mellitus in Kyrgyzstan (according to the state register of diabetes mellitus in the context of 2015)]. Bulletin of KRSU. 2016;16(11):140-144. Russian.

5. Abraham TM, Pencina KM, Pencina MJ, Fox CS. Trends in diabetes incidence: the Framingham Heart Study. Diabetes Care. 2015;38:482-7. doi: https://doi.org/10.2337/dc14-1432

6. Alemu F. Prevalence of Diabetes Mellitus Disease and its Association with Level of Education Among Adult Patients Attending at Dilla Referral Hospital, Ethiopia. Journal of Diabetes and Metabolism. 2015;6(4):521-32.

doi: https://doi.org/10.4172/2155-6156.1000521

7. Alotaibib A, Perry L, Gholizadeh L, AlGonmi A. Incidence and prevalence rates of diabetes mellitus in Saudi Arabia: an overview. Journal of Epidemiology and Global Health. 2017;7:211-18. doi: https://doi.org/10.1016/j.jegh.2017.10.001

8. Estejhamati A, Larijani B, Aghajami M. Diabetes in Iran: prospective analysis from first Nationwide
Diabetes report of National Program for Prevention and control of diabetes (NPPCD - 2016). Scientific Reports. 2017;7:13461.

doi: https://doi.org/10.1038/s41598-017-13379-Z

9. Green A, Sortso C, Jensen PB, Emneus M. Incidence, mortality, morbidity and prevalence of diabetes in Denmark, 2000-2011: results from the Diabetes Impact study 2013. Clinical Epidemiology. 2015;7:421-30. doi: https://doi.org/10.2147/CLEP.S88577

10. Green A, Sortso C, Jensen PB, Emneu SM. Validation of the Danish National Diabetes Register. Clinical Epidemiology. 2015;7:5-15.

doi: https://doi.org/10.2147/CLEP.S72768

11. Javanbakht M, Mashayekhi A, Baradaran HR. Projection of diabetes population size and associated economic burden through 2030 in Iran: Evidence from micro-simulation Markov model and Bayesian meta-analysis. PLOS ONE. 2015;10(7):e0132505. doi: https://doi.org/10.1371/journal.pone.0132505

12. Oshilonya HU, Ijioma SN, Ibeh JN. Prevalence of type -2 diabetes mellitus amongst suspected subjects in Agbor, Delta State, Nigeria and its relationship with age and gender. Archives of Applied Science Research. 2015;7(3):18-20.

13. Scottish Diabetes Survey [Internet]; 2015. Available from: https://www.diabetesinscotland.org.uk/wpcontent/uploads/2019/12/Diabetes-in-Scotland-website-Scottish-Diabetes-Survey-2015.pdf

14. Sinnott S, McHugh S, Whelton H. Estimating the prevalence and incidence of type 2 diabetes using population level pharmacy claims data: a cross - sectional study. BMI Open Diabetes Research and Care. 2017;5:e00288.

doi: https://doi.org/10.1136/bmjdrc-2016-000288

15. State of American well - being. State and community rankings for incidence of diabetes. [Internet]; 2015. Available from: www.well-beingindex.com

\section{СПИСОК ЛІТЕРАТУРИ}

1. Агаева К. Ф., Гусейнли А. Ф. Особенности распространенности сахарного диабета и возрастной ее динамики на современном этапе экономического развития у населения бывшего советского промышленного города. Общественное здоровье $u$ здравоохранение. 2014. № 3. С. 22-24.

2. Викулова О.К. Государственный регистр сахарного диабета РФ: статус 2015 и данные исследований с активным скринингом модуля «Диабет-центр» [Электронный ресурс]. 2016. URL: Diaregistry.ru
3. Дедов И. И., Шестакова М. В., Викулова О. К. Государственный регистр сахарного диабета в Российской Федерации; статус 2014 г. и перспективы развития. Сахарный диабет. 2015. Т. 18, № 3. С. 5-23. DOI: https://doi.org/10.14341/DM201535-22

4. Эпидемиологические аспекты сахарного диабета в Кыргызстане (по данным государственного регистра сахарного диабета в разрезе 2015 г) / Р. Б. Султаналиева и др. Вестник КРСУ. 2016. Т. 16. № 11. C. 140-144. 
5. Abraham T. M., Pencina K. M., Pencina M. J., Fox C. S. Trends in diabetes incidence: the Framingham Heart Study. Diabetes Care. 2015. Vol. 38. P. 482-487. DOI: https://doi.org/10.2337/dc14-1432

6. Alemu F. Prevalence of Diabetes Mellitus Disease and its Association with Level of Education Among Adult Patients Attending at Dilla Referral Hospital, Ethiopia. Journal of Diabetes and Metabolism. 2015. Vol. 6, No. 4. P. 521-532.

DOI: https://doi.org/10.4172/2155-6156.1000521

7. Alotaibib A, Perry L, Gholizadeh L, Al-Gonmi A. Incidence and prevalence rates of diabetes mellitus in Saudi Arabia: an overview. Journal of Epidemiology and Global Health. 2017. Vol. 7. P. 211-218. DOI: https://doi.org/10.1016/j.jegh.2017.10.001

8. Estejhamati A., Larijani B., Aghajami M. Diabetes in Iran: prospective analysis from first Nationwide Diabetes report of National Program for Prevention and control of diabetes (NPPCD - 2016). Scientific Reports. 2017. Vol. 7. P. 13461.

DOI: https://doi.org/10.1038/s41598-017-13379-z

9. Green A, Sortso C, Jensen PB, Emneus M. Incidence, mortality, morbidity and prevalence of diabetes in Denmark, 2000-2011: results from the Diabetes Impact study 2013. Clinical Epidemiology. 2015. Vol. 7. P. 421430. DOI: https://doi.org/10.2147/CLEP.S88577

10. Green A., Sortso C., Jensen P. B., Emneu S. M. Validation of the Danish National Diabetes
Register. Clinical Epidemiology. 2015. Vol. 7. P. 5-15. DOI: https://doi.org/10.2147/CLEP.S72768

11. Javanbakht M, Mashayekhi A, Baradaran HR. Projection of diabetes population size and associated economic burden through 2030 in Iran: Evidence from micro-simulation Markov model and Bayesian metaanalysis. PLOS ONE. 2015. Vol. 10, No. 7. P. e0132505. DOI: https://doi.org/10.1371/journal.pone.0132505

12. Oshilonya HU, Ijioma SN, Ibeh JN. Prevalence of type -2 diabetes mellitus amongst suspected subjects in Agbor, Delta State, Nigeria and its relationship with age and gender. Archives of Applied Science Research. 2015. Vol. 7, No. 3. P. 18-20.

13. Scottish Diabetes Survey [Internet]. 2015. URL: https://www.diabetesinscotland.org.uk/wpcontent/uploads/2019/12/Diabetes-in-Scotland-websiteScottish-Diabetes-Survey-2015.pdf

14. Sinnott S., McHugh S., Whelton H. Estimating the prevalence and incidence of type 2 diabetes using population level pharmacy claims data: a cross - sectional study. BMI Open Diabetes Research and Care. 2017. Vol. 5. P. e00288.

DOI: https://doi.org/10.1136/bmjdrc-2016-000288

15. State of American well - being. State and community rankings for incidence of diabetes. [Internet]. 2015. URL: www.well-beingindex.com 